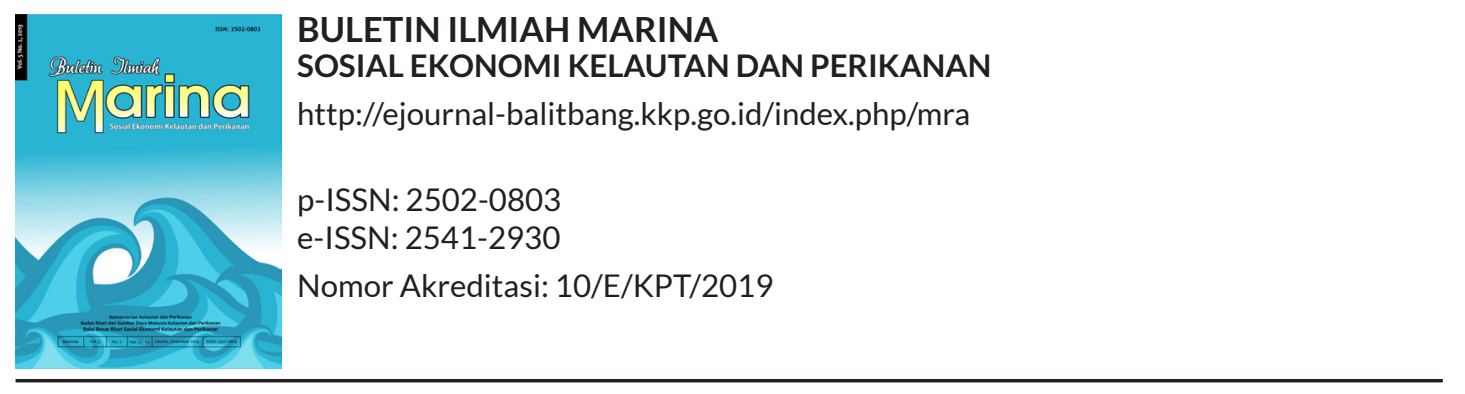

\title{
KARAKTERISTIK SOSIAL EKONOMI NELAYAN DI KALI MARO KABUPATEN MERAUKE, PAPUA
}

\author{
Socio Economic Characteristics of Fishermen in Maro River \\ Merauke Regency, Papua \\ *Maria Maghdalena Diana Widiastuti', Modesta Ranny Maturbongs ${ }^{2}$, Sisca Elviana ${ }^{2}$, \\ Chair Rani ${ }^{3}$, dan Andi lqbal Burhanuddin ${ }^{3}$ \\ 1 Jurusan Agribisnis, Universitas Musamus Merauke \\ Jl. Kamizaun Mopah Lama, Rimba Jaya, Kec. Merauke, Kabupaten Merauke, Papua 99600 \\ 2Jurusan Manajemen Sumberdaya Perairan, Universitas Musamus Merauke \\ ${ }^{3}$ Departemen IImu Kelautan, Universitas Hasanuddin Makassar
}

Diterima tanggal: 10 Desember 2019 Diterima setelah perbaikan: 8 November 2020

Disetujui terbit: 21 Desember 2020

\begin{abstract}
ABSTRAK
Pengelolaan Daerah Aliran Sungai Maro membutuhkan data komprehensif mengenai aktivitas pemanfaatan sungai tersebut. Tujuan penelitian ini mengidentifikasi karakteristik sosial ekonomi nelayan yang menangkap ikan di Kali Maro. Metode penelitian ini deskriptif analitis dengan pengambilan data nelayan menggunakan FGD (Focus Group Discussion). Kriteria responden adalah nelayan (pemilik dan anak buah kapal) yang mengambil ikan di muara dan Kali Maro. Jumlah responden sebanyak delapan belas orang. Hasil penelitian menunjukkan bahwa karakteristik nelayan di Kali Maro merupakan nelayan kecil dengan kepemilikan perahu kecil (semang) rata-rata 1 unit dengan kapasitas maksimum 2 ton. Jenis ikan yang diperoleh antara lain ikan kakap, ikan kuru, ikan kaca, ikan bandeng, ikan gulama, ikan duri, dan ikan herkules. Kalender musim menurut nelayan terbagi menjadi dua, yaitu musim ikan melimpah (Oktober - Februari) dan musim ombak yang menandakan sedikitnya tangkapan ikan (Maret - September). Sistem penangkapan dilakukan sendiri dengan tenaga kerja didominasi dari dalam keluarga. Pemasaran melalui pemborong langganan dengan model konsinyasi. Kelembagaan nelayan belum berfungsi sebagai produksi, media belajar, dan pemasaran. Regulasi secara adat hanya terjadi di hulu sungai, sedangkan di muara sungai tidak ada aturan informal maupun formal yang mengatur aktivitas perikanan di sungai. Biaya operasional per trip sebesar Rp462.835,00 dengan komponen terbesar bensin dan oli sebesar $42 \%$. Belum ditemukan adanya hubungan agent principle yang tidak menguntungkan nelayan. Saran dari penelitian ini adalah menggerakan modal sosial nelayan untuk membentuk kelembagaan informal dan membangun regulasi yang mengatur aktivitas penangkapan ikan, pemasaran, sistem bagi hasil dengan ABK. Perlunya dukungan pemerintah untuk peningkatan alat tangkap, modernisasi moda transportasi dan sistem penyimpanan hasil, sistem rantai pasok pemasaran, serta membangun industri pengolahan hasil.
\end{abstract}

Kata Kunci: sosial ekonomi; nelayan; Kali Maro; Merauke; modal sosial

\section{ABSTRACT}

Management of the Maro river need a comprehensive data of all activities in the river. The study aimed to identify the socio-economic characteristics of fishermen who catch fish in Maro River. Descriptive analysis were used The methodology is analytical descriptive by collecting fishermen data using FGD (Focus Group Discussion). Respondents' criteria are fishermen (owners and crew members) who take fish in the estuary and the Maro River. The number of respondents are 18 people. The results of the study indicate that the characteristics of the fishermen in the Maro River are small fishermen with a small boat with boat ownership an average of 1 unit with maximum capacity 2 tonnes. Catch fish in Maro 
River as main livelihood. Fish types obtained include: Snapper, kuru, glass, milkfish, gulama, thorny fish and hercules. The season calendar according to fishermen is divided into 2 namely abundant fish season (October to February) and the wave season which indicates the small number of fish catches (March to September). The fisherman catch fish alone or with labor dominated from family member. Selling fish through subscriptions contractor with a consignment model. The fishermen's institution has not functioned as a production, learning and marketing. There is custom regulation in upstream but no informal of formal regulation to manage fisheries activities in dowwnstream. Operational costs per trips Rp.462,835.00 with the largest component of gasoline and oil by 42 percent. There is no unfair agent principle relationship. Suggestions from this research are build the social capital of fishermen to form informal institutions and conduct regulations for fishing activities, marketing, profit sharing systems with crew members. Need government support to improvement of fishing gear, modernization of transportation modes and yield storage systems, marketing supply chain systems and build a processing industry.

Keywords: socio economy; fishermen; Maro River; Merauke, social capital

\section{PENDAHULUAN}

\section{Latar Belakang}

Kali merupakan sebutan dari sungai bagi masyarakat di Merauke, Papua. Kali Maro adalah salah satu dari sebelas kali yang ada di Kabupaten Merauke yang bermuara di Laut Arafura. Membentang dari Barat Daya menuju Timur Laut, Kali Maro melewati tujuh wilayah administrasi (distrik) dengan hulu sungai berada di negara Papua New Guinea. Distrik yang dilewati Kali Maro dari hilir hingga hulu adalah Distrik Merauke, Semangga, Tanah Miring, Jagebob, Sota, dan Muting. Panjang Kali Maro 207 km dan lebar 48-900 m, merupakan salah satu sungai terbesar dan berkelok-kelok di Kabupaten Merauke yang berfungsi sebagai jalur transportasi menuju kampung dan distrik lain juga menjadi tempat mata pencaharian nelayan perikanan darat bagi masyarakat di pesisir pantai dan sepanjang Daerah Aliran Sungai (DAS) Maro. Jarak Kelurahan Kamahedoga dan kantor Bupati Merauke adalah $2 \mathrm{~km}$. Jumlah penduduk di Kelurahan Kamahedoga terdata sebanyak 385 KK dengan mayoritas penduduk bermata pencaharian sebagai nelayan (buruh dan pemilik kapal atau perahu semang).

Potensi perikanan darat di sepanjang DAS ini sangat besar. Data volume produksi perikanan sungai di Kabupaten Merauke tercatat 2.027 ton pada tahun 2017 (Kementerian Kelautan dan Perikanan, 2018). Penelitian Sugianti \& Satria (2007) menyebutkan bahwa terdapat 19 jenis ikan yang memiliki nilai ekonomis di Kali Maro, antara lain ikan kakap batu (Datnicides sp), kaca (Parambasis sp), sembilang (Toundanus sp), mujair (Oreochromis Mossambiscus), gabus (Channa $\mathrm{sp}$ ), udang putih (Macrobranchium sp), bulanak (Valamugil sp) dan jenis kakap lainnya termasuk ikan arwana irian (Sclerophages Jardinii) yang merupakan ikan hias yang dilindungi. Penelitian dua belas tahun silam tersebut menyimpulkan potensi perikanan di Sungai Maro sangat besar dan belum optimal karena nelayan masih menggunakan alat tangkap tradisional berupa kaboti yang menyerupai bubu, pancing sederhana yang terdiri dari bambu/botol sebagai joran, benang nilon dan kail, tombak/kalawai juga masih digunakan. Alat tangkap kakap atau ikan arwana sudah menggunakan gill net atau jaring insang.

Potensi perikanan tangkap di sungai yang cukup besar, seharusnya diikuti pula oleh tingkat kesejahteraan yang tinggi dari nelayan atau masyarakat di pesisir sungai. Namun, penelitian Widiastuti \& Sunarni (2018) menyebutkan bahwa dalam satu bulan rata-rata pendapatan nelayan di pesisir sebesar Rp500.000,00 - Rp1.000.000,00. Penelitian Sugianti \& Satria (2007) menunjukkan bahwa masyarakat di pesisir Kali Maro masih sangat tergantung dari hasil tangkapan ikan di kali padahal mata pencaharian yang mengandalkan sumber daya alam sangat tergantung pada faktor alam seperti musim.

Fenomena yang terjadi di Kali Maro saat penelitian ini berlangsung adalah banyaknya perahu-perahu yang melakukan penangkapan ikan di Kali Maro sehingga dikhawatirkan dapat terjadi over fishing yang mempengaruhi ketersediaan sumber pangan bagi masyarakat lokal dan penurunan tingkat kesejahteraan nelayan. Oleh karena itu, penelitian ini dapat menjadi pengetahuan awal mengenai gambaran umum nelayan di Kali Maro, aktivitas penangkapan ikan, pengetahuan masyarakat tentang musim, dan aktivitas sosial dan ekonomi masyarakat. Tujuan penelitian ini adalah mengidentifikasi karakter sosial ekonomi nelayan sebagai aktor dalam aktivitas penangkapan ikan di Kali Maro, dan menganalisis modal sosial dalam pemanfaatan Kali Maro. 


\section{Pendekatan IImiah}

Penelitian ini dilakukan di muara Kali Maro tepatnya di Kelurahan Kamahedoga, Distrik Maro, Kabupaten Merauke (Gambar 1) pada stasiun penelitian dua. Pemilihan lokasi ini karena wilayah Kelurahan Kamahedoga merupakan salah satu wilayah DAS Maro yang memiliki perkampungan nelayan dan aktivitas penangkapan terbanyak di muara sungai. Mayoritas penduduk yang tinggal di muara Sungai Maro adalah pendatang. Penelitian dilaksanakan pada bulan Juli hingga Agustus 2019.

Kegiatan pengumpulan data dilakukan menggunakan Focus Group Discussion (FGD) sebanyak dua kali dengan jumlah peserta masingmasing sembilan orang. FGD merupakan salah satu metode pengumpulan data untuk penelitian kualitatif dengan tujuan untuk mendiskusikan permasalahan tertentu dan memperoleh gambaran perspektif mengenai kondisi di suatu wilayah. Jumlah peserta FGD antara 8-12 orang yang memiliki pengetahuan yang kurang lebih sama mengenai topik yang akan dibahas dengan dipandu oleh seorang fasilitator (Wahyuni, 2014). Metode ini dipilih untuk lebih mengetahui secara mendalam mengenai kondisi sosial ekonomi nelayan yang mengambil ikan di Kali Maro. Karakteristik peserta FGD terbatas pada nelayan pemilik kapal semang dan Anak Buah Kapal (ABK) yang aktif melakukan penangkapan ikan lima tahun terakhir. Diperoleh jumlah $A B K$ sebanyak 8 orang dan 10 orang pemilik kapal semang. Data sekunder diperoleh dari Dinas
Kelautan dan Perikanan Kabupaten Merauke mengenai hasil tangkapan ikan, data BPS melalui buku Merauke Dalam Angka 2017, serta sumber pustaka lain yang berasal dari jurnal dan hasil penelitian yang relevan dengan topik penelitian.

Analisis data dilakukan secara deskriptif dari hasil FGD yang berupa data kualitatif kemudian ditranskripsi dengan cara mengumpulkan semua informasi dan memilah data yang sama untuk dianalisis jawaban dan keterkaitan antara satu informan dengan informan lainnya. Selanjutnya, data kuantitatif ditabulasi dan dianalisis dengan statistika deskriptif. Serta data sekunder digunakan untuk melengkapi hasil pengumpulan data melalui FGD.

\section{KARAKTERISTIK NELAYAN}

Kelurahan Kamahedoga merupakan kelurahan pemekaran dari Kelurahan Gudang Arang, Distrik Merauke yang baru terbentuk pada tahun 2017. Oleh karena itu, ketersediaan data monografi kelurahan masih sangat minim dan tidak terdapat data berapa populasi nelayan di kelurahan ini. Berdasarkan informasi dari peserta FGD diperkirakan sebagian besar penduduk di Kamahedoga berprofesi sebagai nelayan. Jumlah penduduk di Kelurahan Kamahedoga dari Data Monografi Kelurahan 2020, sebanyak 1.519 orang, yang terdiri dari 765 berjenis kelamin laki-laki dan 754 perempuan (Kelurahan Kamahedoga, 2020). Nelayan yang melakukan penangkapan ikan di Kali Maro merupakan nelayan kecil.

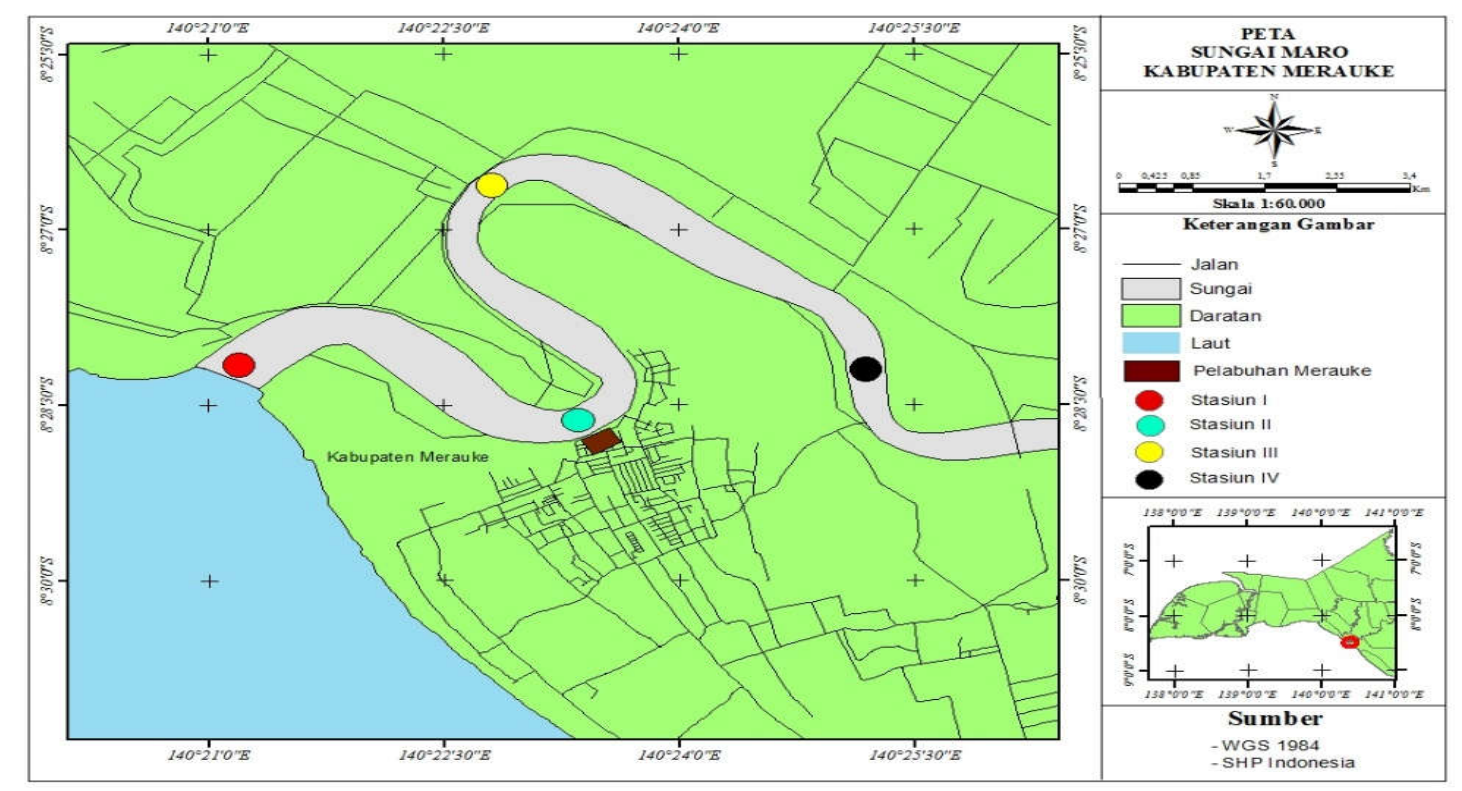

Gambar 1. Wilayah Lokasi Penelitian (Stasiun II). Sumber: Data Primer Diolah 
Menurut UU Nomor 45 Tahun 2009, definisi nelayan kecil adalah orang yang mata pencahariannya menangkap ikan dengan menggunakan kapal berukuran paling besar 5 GT (Gross Tonase). Semua nelayan di Kali Maro menggunakan kapal kecil dengan menggunakan mesin ketinting yang biasa disebut semang. Ukuran semang bervariasi antara 3-9 meter dengan kapasitas berkisar $50 \mathrm{~kg}$ hingga 5 ton. Rata-rata ukuran kapal yang dimiliki oleh nelayan berkapasitas 2 ton (Tabel 1). Ukuran kapal ini berpengaruh terhadap hasil tangkapan maksimal yang bisa diperoleh dan akhirnya berdampak terhadap pendapatan yang diperolehnya (Vibriyanti, 2019)

Kategori nelayan berdasarkan kepemilikan kapal yang terdapat dalam UU Nomor 16 Tahun 1964 tentang sistem bagi hasil di bidang perikanan menyebutkan ada yang disebut nelayan penggarap dan ada yang disebut nelayan pemilik/ juragan serta nelayan pandega. Peserta FGD adalah pemilik kapal sebanyak $56 \%$ dan sekaligus nelayan pandega karena ikut serta dalam usaha penangkapan ikan dan anak buah kapal (ABK) sebanyak 44\%. Mayoritas nelayan di Kali Maro adalah nelayan pendatang $(61 \%)$ dan nelayan lokal (39\%). Sebagian besar pemilik kapal adalah pendatang yang memiliki kapal sendiri. ProfesiABK juga sebagian besar didominasi oleh pendatang. Hal ini karena lokasi penelitian terletak di muara sungai dan lebih dekat ke Kota Merauke.

Umur nelayan rata-rata berkisar 41 tahun dengan pengalaman menjadi nelayan rata-rata 23 tahun. Usia produktif sebagai tenaga kerja dan dengan pengalaman yang tergolong lama menjadi keunggulan para nelayan ini dalam menekuni dan menjadikannya sebagai mata pencaharian utama. Hasil FGD menunjukkan bahwa $61,1 \%$ peserta FGD termasuk dalam nelayan sambilan utama yang memiliki pekerjaan sampingan dan $38,9 \%$ sebagai nelayan penuh. Nelayan yang memiliki sambilan selain nelayan berprofesi antara lain sebagai buruh bangunan, supir, buruh pelabuhan, dan membuat jaring/perahu. Nelayan di Kali Maro banyak yang memiliki pekerjaan sambilan karena ada kondisi musim ikan yang sedikit, mengikuti musim angin barat dan timur di laut, terutama untuk nelayan dengan kapasitas kapal yang kecil dan hanya mengambil ikan di muara sungai. Walaupun musim angin barat dan timur tidak berdampak langsung terhadap cuaca di hulu sungai, namun sangat berpengaruh terhadap ketersediaan ikan di kali. Ditambah fenomena sekarang dengan banyaknya jumlah kapal yang mencari ikan di kali, jumlah tangkapan menjadi lebih sedikit.

Sebanyak $57 \%$ peserta FGD yang tidak memiliki pekerjaan sampingan merupakan nelayan lokal, yang berarti bahwa $43 \%$ peserta FGD yang memiliki pekerjaan sampingan adalah nelayan pendatang. Hal ini disebabkan beberapa profesi sampingan seperti buruh bangunan, supir, membuat perahu atau jaring membutuhkan ketrampilan. Nelayan lokal ini rata-rata tidak memiliki ketrampilan tersebut. Buruh angkut pelabuhan tidak membutuhkan ketrampilan, tetapi cenderung sulit untuk mendaftar sebagai buruh angkut karena ada faktor kedekatan dengan ketua tim ataupun dengan pihak pelabuhan dalam rekrutmen. Mereka biasanya memiliki orang-orang tertentu yang sudah ditunjuk untuk bergabung atau yang pernah ikut terlibat sebelumnya dengan tim buruh angkut kapal.

Kondisi nelayan di Kali Maro hampir sama kondisinya dengan nelayan tangkap di laut. Penelitian Widiastuti \& Sunarni (2018) membandingkan sosial ekonomi nelayan tangkap di laut antara nelayan pendatang dan nelayan lokal menemukan bahwa $28,9 \%$ nelayan pendatang memiliki pekerjaan sampingan, sedangkan nelayan lokal hanya $9,5 \%$ yang memiliki pekerjaan sampingan. Nikijuluw (2012) menyatakan bahwa pekerjaan sampingan bagi nelayan merupakan "keharusan" karena pekerjaan sebagai nelayan sangat dipengaruhi oleh faktor eksternal seperti angin, musim, dan kondisi alam lainnya di luar kontrol manusia. Begitu pula yang terjadi pada nelayan di Kabupaten Ciamis, Patriana \& Satria (2013) menyebutkan bahwa beberapa aktivitas adaptif yang dilakukan nelayan berupa mencari ikan di wilayah mangrove dan di daerah lain, memiliki mata pencaharian ganda dengan pola nelayan-petani atau nelayan-buruh bangunan, dan beralih profesi keluar dari sektor perikanan.

Tingkat pendidikan yang ditempuh oleh para nelayan peserta FGD ini sebagian besar adalah lulusan sekolah dasar (SD) $(28 \%)$, sekolah menengah pertama (SMP) (55\%), sekolah menengah kejuruan (SMK) (6\%), dan tidak tamat SD (11\%). Pendidikan yang relatif rendah ini diduga karena rendahnya motivasi anak dan orang tua untuk mengeyam pendidikan yang lebih tinggi. Selain itu, bantuan pemerintah untuk program wajib belajar 9 tahun hanya diperoleh hingga jenjang SMP, sedangkan untuk tingkat sekolah menengah atas (SMA) atau sederajat dibutuhkan 
Tabel 1. Karakteristik Nelayan Penangkap Ikan di Kali Maro, Merauke Tahun 2019.

\begin{tabular}{|c|c|c|c|c|c|c|c|c|c|}
\hline No & JK & $\begin{array}{c}\text { lokal/ } \\
\text { pendatang }\end{array}$ & Umur & Pendidikan & $\begin{array}{l}\text { Pengala } \\
\text { man (thn) }\end{array}$ & Sampingan & $\begin{array}{l}\text { Jmlh } \\
\text { kapal }\end{array}$ & $\begin{array}{c}\text { Ukuran } \\
\text { Kapal (GT) }\end{array}$ & Status \\
\hline 1 & $\mathrm{~L}$ & $L$ & 46 & - & 30 & Berburu & 0 & & $\mathrm{ABK}$ \\
\hline 2 & $\mathrm{~L}$ & $\mathrm{P}$ & 20 & SMP & 1 & Tukang bangunan & 0 & & ABK \\
\hline 3 & $\mathrm{~L}$ & $\mathrm{P}$ & 45 & SD & 30 & Sensor Kayu & 0 & & $\mathrm{ABK}$ \\
\hline 4 & $\mathrm{~L}$ & $P$ & 49 & SD & 38 & Menjaring sendiri & 0 & & $\mathrm{ABK}$ \\
\hline 5 & $\mathrm{~L}$ & $\mathrm{P}$ & 47 & SMP & 30 & Tidak ada & 0 & & ABK \\
\hline 6 & $\mathrm{~L}$ & L & 39 & SMP & 5 & Berburu & 0 & & ABK \\
\hline 7 & $\mathrm{~L}$ & $P$ & 33 & SMP & 16 & Tukang bangunan & 0 & & ABK \\
\hline 8 & $\mathrm{~L}$ & L & 37 & SMP & 4 & Tidak ada & 0 & & $\mathrm{ABK}$ \\
\hline 9 & $\mathrm{~L}$ & $\mathrm{P}$ & 47 & SMP & 37 & Buruh bangunan & 2 & 1 dan 2 & Pemilik \\
\hline 10 & $\mathrm{~L}$ & L & 60 & SMP & 50 & Istirahat & 1 & 2 & Pemilik \\
\hline 11 & $\mathrm{~L}$ & $P$ & 53 & SD & 37 & tidak ada & 1 & 2 & Pemilik \\
\hline 12 & $\mathrm{~L}$ & L & 37 & SMP & 10 & $\begin{array}{c}\text { berkebun/beternak } \\
\text { babi }\end{array}$ & 1 & 2 & Pemilik \\
\hline 13 & $\mathrm{~L}$ & $P$ & 23 & SD & 16 & buruh pelabuhan & 1 & 2 & Pemilik \\
\hline 14 & $\mathrm{~L}$ & L & 39 & - & 28 & tidak ada & 1 & 1 & Pemilik \\
\hline 15 & $\mathrm{~L}$ & $\mathrm{P}$ & 40 & SMK & 20 & supir & 1 & 5 & Pemilik \\
\hline 16 & $\mathrm{~L}$ & $P$ & 42 & SMP & 37 & tidak ada & 2 & 15 & Pemilik \\
\hline 17 & $\mathrm{~L}$ & L & 25 & SMP & 4 & $\begin{array}{c}\text { tidak ada } \\
\text { buruh bangunan, }\end{array}$ & 2 & 1 dan 2 & $\begin{array}{l}\text { Pemilik } \\
\text { Pemilik }\end{array}$ \\
\hline 18 & $\mathrm{~L}$ & $\mathrm{p}$ & 54 & SD & 33 & $\begin{array}{l}\text { buat kapal dan } \\
\text { jaring }\end{array}$ & 1 & 1 & \\
\hline
\end{tabular}

Sumber: Data Primer Diolah

biaya pendidikan yang lebih besar. Tidak ada kesulitan dalam akses memperoleh pendidikan yang lebih tinggi, karena sekolah SMA tersedia di lokasi wilayah tempat tinggal penduduk.

Alat tangkap yang digunakan oleh nelayan tergantung pada musim jenis ikan. Rata-rata terdiri dari jaring 5-25 keping, jaring mata 7-11, jaring insang hanyut, masing - masing jumlah jaring yang dibawa dalam satu kali trip antara 5-12 buah. Saat ini telah terjadi penambahan jumlah alat tangkap dan jenis alat tangkap jika dibandingkan dengan penelitian Sugianti \& Satria (2007) yang menyatakan bahwa nelayan Kali Maro pada saat penelitian menggunakan alat tangkap tradisional berupa pancing, bubu, dan gill net. Pengetahuan informan dalam hal teknis pengambilan ikan, mengamati cuaca, dan arus air sudah bagus. Hal ini dapat diketahui dari informasi saat FGD. Penggunaan alat tangkap bagi nelayan membutuhkan kemampuan dan pengalaman. Kesalahan dalam menebarkan jaring akan membuat jaring robek atau rusak sehingga berpotensi menambah biaya produksi. Begitu pula dengan penambatan kapal saat hauling, jika air pasang biasanya ikan berada di pinggir kali untuk menghindari arus air pasang, sedangkan perahu semang memiliki keterbatasan untuk berlabuh di sepanjang pinggir kali karena banyak terdapat kayu/ranting/sampah yang dapat menyebabkan rusaknya jaring dan mesin perahu. Oleh karena itu, dibutuhkan ketrampilan dan juga pengetahuan lokal dalam melakukan aktivitas pencarian ikan di Kali Maro.

\section{AKTIVITAS PENANGKAPAN IKAN DI KALI MARO}

Gambaran perekonomian nelayan di Kali Maro, dapat diketahui dari aktivitas penangkapan yang biasa dilakukan oleh nelayan yang mengambil ikan di sepanjang Kali Maro. Berdasarkan informasi tersebut dapat diestimasi kondisi perekonomian nelayan, pengetahuan nelayan mengenai DAS Maro, permasalahan yang sering muncul dari aktivitas yang dilakukannya, dan hal-hal lain lebih mendalam yang tidak terungkap dengan menggunakan data kuantitatif.

Informasi kegiatan penangkapan ikan yang diperoleh melalui FGD bahwa tidak ada jadwal khusus dalam menangkap ikan di kali, masingmasing nelayan memiliki waktu yang berbeda dalam pengambilan ikan. Sebagian besar nelayan mengikuti arus pasang surut air laut. Dalam satu hari, rata-rata 1-2 kali turun mencari ikan dengan waktu rata-rata 5,75 jam per trip, 
muali dari jam 11.00 - 15.00 atau berangkat malam pada pukul 23.00 - 04.00. Daya tampung tangkapan ikan yang terbatas dan juga kualitas ikan yang harus tetap segar hingga pelabuhan, membuat nelayan ini tidak bisa terlalu lama dalam mencari ikan. Kapal bermotor masih memungkinkan mencari ikan hingga ke hulu kali. Namun, hanya sedikit nelayan yang memiliki kapal jenis ini. Adapun jumlah nelayan yang memiliki perahu semang berdasarkan data Dinas Perikanan dan Kelautan Kabupaten Merauke (2018) sebanyak 128 orang, pemilik perahu ketinting 88 orang, dan perahu motor dengan kapasitas 5-10 GT sebanyak 31 usaha dengan 5 kapal yang melakukan penangkapan ikan di perairan Merauke.

Keterbatasan waktu penangkapan ikan di kali juga mempengaruhi pendapatan nelayan. Lama waktu hauling di sungai rata-rata 5,75 jam dengan rata-rata waktu tempuh perjalanan selama 2,3 jam. Nelayan tidak memungkinkan untuk melakukan perjalanan jauh dalam mencari ikan karena keterbatasan armada. Tidak ada cold storage di dalam semang karena badan perahu yang relatif kecil. Adapun perahu semang dapat dilihat pada Gambar 2. Bahkan ada juga yang tidak menggunakan es batu karena justru akan membuat ikan menjadi cepat busuk karena es mencair akan menggenangi hasil tangkapan ikan. Tidak ada lokasi spesifik yang dituju oleh para nelayan sebagai fishing ground.

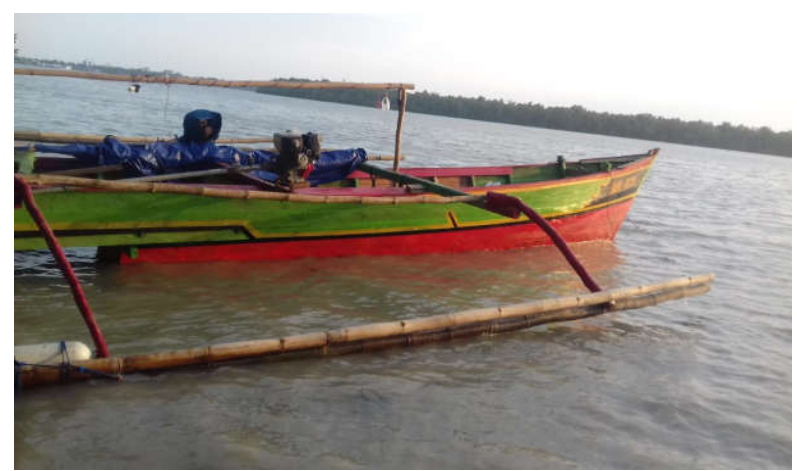

Gambar 2. Perahu Semang Nelayan di Kali Maro dengan Kapasitas 2-5 ton.

Sumber: Dokumentasi Pribadi

Kalender musim menurut masyarakat, terbagi menjadi 2 bagian yaitu pada bulan Oktober sampai dengan Februari yang disebut musim angin barat yang ditandai dengan melimpahnya ikan dan bulan Maret sampai September yang disebut sebagai musim ombak karena angin timur, angin kencang, dan ikan sulit diperoleh. Pada musim angin barat, jenis ikan yang disebutkan oleh nelayan relatif banyak dan bervariasi jenisnya, sedangkan pada musim angin timur jenis ikan dan jumlahnya juga sedikit. Hal ini sesuai dengan pola musim yang disampaikan oleh Nontji (1987) yang menyatakan bahwa musim penangkapan ikan sangat dipengaruhi oleh pola musim. Pola musim dipengaruhi oleh pola arus dan pola arah angin.

Berdasarkan musim penangkapan ikan di Indonesia dikenal empat musim, yaitu angin barat, musim angin timur, musim peralihan 1 (awal tahun), dan musim peralihan 2 (akhir tahun). Hasil FGD nelayan sesuai dengan teori musim Nontji di atas, menurut nelayan pada bulan April - Agustus merupakan musim ikan sedikit, karena pada saat tersebut sedang musim peralihan 1 dan angin musim timur. Ikan kembali melimpah pada bulan September - Maret pada saat musim peralihan 2 atau pancaroba akhir tahun dan musim angin barat. Nelayan selalu memperoleh jenis-jenis ikan tertentu setiap bulan meskipun jumlah tangkapan sedikit dan didominasi ikan dengan ukuran kecil pada musim peralihan dan musim angin timur. Ada 18 jenis ikan dengan didominasi oleh ikan kakap, bandeng yang melimpah pada musim angin barat dan ikan jenis kuru, kaca, hercules yang tetap diperoleh pada musim angin timur. Banyaknya jenis ikan yang diperoleh sesuai dengan penelitian Elviana, Modesta, Sunarni, Rani, \& Burhanuddin (2019) dan Mote, Ayarau, \& Sisca (2019) yang mengidentifikasi setidaknya terdapat 18 jenis ikan di Kali Maro pada musim peralihan 1 atau pada bulan April -Mei 2019 dan Februari - April 2018. Jika dibandingkan dengan penelitan Sugianti \& Satria (2007), terdapat 19 jenis ikan yang ditemui di Kali Maro pada bulan April, Juli, September, dan November 2006. Ada satu jenis ikan yang mulai punah atau jarang ditemui oleh nelayan, yaitu jenis ikan hias atau ikan bambit. Hal ini kemungkinan karena sejak di hulu sungai, ikan ini sudah ditangkap untuk diperjualbelikan. Bahkan anakan ikan hias ini banyak dicari oleh pemburu ikan hias. Pada Tabel 2 juga dapat dilihat bahwa terdapat beberapa jenis ikan yang tetap diperoleh pada musim angin barat dan angin timur, yaitu jenis ikan kaca. Ikan ini ditemukan melimpah pada sepanjang musim. Hal ini sesuai dengan penelitian Mote et al., (2019) tentang kelimpahan ikan kaca. Ikan kakap dan gulama juga banyak dicari oleh nelayan, selain karena ikannya, nelayan juga mengambil gelembung ikan tersebut untuk dijual. Harga gelembung berkisar 2 - 5 juta rupiah per $\mathrm{kg}$. 
Tabel 2. Jenis-jenis Ikan Hasil Tangkapan Nelayan di Kali Maro Di Tahun 2019.

\begin{tabular}{|c|c|c|c|c|}
\hline Bulan & Jenis ikan & Nama Latin & Jumlah (Ton) & Angin \\
\hline \multirow{9}{*}{ Jan } & Kakap rawa/putih & Lates carcarifer & $1-2$ & Barat \\
\hline & Kuru & Eleutheronema tetradactylum & & \\
\hline & Bandeng & Chanos chanos & & \\
\hline & Hercules & Arius sp & & \\
\hline & Gulama & Nibeasoldado & & \\
\hline & Kaca & Parambasis sp & & \\
\hline & Duri & Arius latirostris & & \\
\hline & Bulanak & Valamugil sp & & \\
\hline & Mujair & Oreochromis mossambicus & & \\
\hline \multirow[t]{11}{*}{ Feb } & Kakap rawa/putih & Lates carcarifer & $1-2$ & Barat \\
\hline & Kakap batu & Datnioides campbelli & & \\
\hline & Kuru & Eleutheronema tetradactylum & & \\
\hline & Bandeng & Chanos chanos & & \\
\hline & Hercules & Arius sp & & \\
\hline & Gulama & Nibeasoldado & & \\
\hline & Kaca & Parambasis sp & & \\
\hline & Duri & Arius latirostris & & \\
\hline & Bulanak & Valamugil sp & & \\
\hline & Mujair & Oreochromis mossambicus & & \\
\hline & Bawal & Colossoma sp & & \\
\hline \multirow[t]{7}{*}{ Mrt } & Kuru & Eleutheronema tetradactylum & $0,5-1$ & Barat \\
\hline & Kaca & Parambasis sp & & \\
\hline & Kakap rawa/putih & Lates carcarifer & & \\
\hline & Gulama & Nibeasoldado & & \\
\hline & Bata-bata & Rhinoprenes pentanemus & & \\
\hline & Bulanak & Valamugil sp & & \\
\hline & Udang & Macrobrachium sp & & \\
\hline \multirow[t]{3}{*}{ Apr } & Kaca & Parambasis sp & $0,1-0,5$ & Timur \\
\hline & Kuru & Eleutheronema tetradactylum & & \\
\hline & Gulama & Nibeasoldado & & \\
\hline \multirow[t]{3}{*}{ Mei } & Kuru & Eleutheronema tetradactylum & $0,1-0,5$ & Timur \\
\hline & Hercules & Arius sp & & \\
\hline & Bete-bete & Rhinoprenes pentanemus & & \\
\hline Jun & Kaca & Parambasis sp & $<0,1$ & Timur \\
\hline \multirow[t]{2}{*}{ Jul } & Kuru & Eleutheronema tetradactylum & $<0,1$ & Timur \\
\hline & Kakap rawa/putih & Lates carcarifer & & \\
\hline \multirow[t]{2}{*}{ Agust } & Kuru & Eleutheronema tetradactylum & $<0,1$ & Timur \\
\hline & Hercules & Arius sp & & \\
\hline \multirow[t]{6}{*}{ Sept } & Kakap rawa/putih & Lates carcarifer & $0,1-0,5$ & Barat \\
\hline & Kakap batu & Datnioides campbelli & & \\
\hline & Kuru & Eleutheronema tetradactylum & & \\
\hline & Gulama & Nibeasoldado & & \\
\hline & Bulanak & Valamugil sp & & \\
\hline & Duri & Arius latirostris & & \\
\hline \multirow[t]{8}{*}{ Okt -Des } & Kakap rawa/putih & Lates calcaliver & $1-2$ & Barat \\
\hline & Kakap batu & Datnioides campbelli & & \\
\hline & Kuru & Eleutheronema tetradactylum & & \\
\hline & Gulama & Nibeasoldado & & \\
\hline & Bulanak & Valamugil sp & & \\
\hline & Duri & Arius latirostris & & \\
\hline & Mujair & Oreochromis mossambicus & & \\
\hline & Kaca & Parambasis sp & & \\
\hline
\end{tabular}

Sumber: Hasil FGD (2019) 
Aturan formal maupun informal belum tersedia terkait dengan penangkapan ikan di Kali Maro. Wilayah kepala kali (hulu sungai) yang banyak didiami oleh masyarakat lokal, dikenal adanya aturan adat sasi yang melarang pengambilan hasil ikan pada kurun waktu tertentu. Teraka (2019) menyebutkan bahwa saat ini adat sasi tidak lagi ditegakkan oleh pemilik adat karena faktor ekonomi dan banyaknya pelanggar sasi yang tidak dikenakan sanksi sesuai dengan aturan yang telah disepakati. Pendatang pun tidak terikat dengan sasi, sehingga tidak ada tindakan tegas dari pemilik adat. Aturan adat sasi sangat baik jika diterapkan di muara sungai, namun perlu adanya kajian lebih lanjut mengenai aspek ketaatan dan dampaknya. Mekanisme aturan adat yang berhasil dilakukan di daerah lain dalam hal pengelolaan wilayah pesisir seperti yang terjadi pada masyarakat di Sumatra Barat dengan adanya adat lubuk larangan. Lubuk larangan memiliki dampak yang positif terhadap masyarakat karena dapat menjaga kelestarian sumber daya ikan sehingga tetap memperoleh hasil perikanan yang optimal di saat tertentu dan di saat lain alam pun mampu me-recovery diri dan memberikan waktu bagi ikan untuk perkembangbiakan. Selain itu adanya lubuk larangan ini juga memberikan peningkatan perekonomian kepada masyarakat sekitar dengan "menjual" tradisi lubuk larangan menjadi aktivitas ekowisata, sehingga masyarakat memperoleh tambahan pendapatan dari aktivitas wisata tersebut (Firdaus \& Huda, 2015).

\section{ASPEK EKONOMI PENANGKAPAN IKAN DI KALI MARO}

Ruang lingkup aspek ekonomi dalam penelitian ini berkaitan dengan pola rantai pasok hasil penangkapan ikan di Kali Maro dan analisis usaha penangkapan ikan. Modal yang digunakan oleh nelayan per trip keberangkatan terdiri dari bahan bakar berupa bensin, es/garam, bahan makanan, dan biaya tenaga kerja bagi yang menggunakan $\mathrm{ABK}$. Adapun biaya rata-rata yang dibutuhkan untuk satu trip perjalanan seperti terdapat pada Tabel 3.

Rata-rata biaya variabel yang dibutuhkan untuk satu kali trip penangkapan sebesar Rp462.835,00. Komponen pembiayaan terbesar adalah untuk bahan bakar berupa bensin dan oli sebesar $41 \%$ dan bahan makanan berupa air minum, makan, sirih, dan pinang, serta rokok sebesar $32 \%$. Harga bensin yang diberikan merupakan harga bensin eceran sebesar Rp8.100,00. Nelayan ini sulit mengakses bensin subsidi untuk nelayan karena keterbatasan stok dan harus antri untuk waktu yang cukup lama, sehingga mereka seringkali membeli bahan bakar di tempat umum. Padahal subsidi paling besar di sektor perikanan adalah subsidi BBM, bahkan di dunia tercatat $22 \%$ total subsidi adalah BBM, 20\% manajemen, dan $10 \%$ untuk pelabuhan (Sumaila, Lam, Le Manach, Swartz, \& Pauly, 2016). Upah ABK menggunakan sistem bagi hasil dengan dikurangi modal/bahan makanan yang digunakan untuk mencari ikan. Sistem bagi hasil bagi tenaga kerja dalam keluarga sedikit berbeda dengan tenaga kerja yang diambil dari luar keluarga. Biasanya untuk tenaga kerja dalam keluarga pembagiannya adalah 1:4. Berbeda dengan sistem bagi hasil tenaga kerja luar keluarga, biasanya diterapkan sistem $50 \%$ setelah dikurangi modal. Namun demikian, tenaga kerja dalam keluarga lebih diutamakan dibandingkan tenaga kerja dari luar keluarga. Sistem bagi hasil ini memang tidak memenuhi aspek equity, karena sangat merugikan ABK. Berdasarkan UU Nomor 11 Tahun 1964, sistem pembagian ini sudah sesuai dengan aturan main yang berlaku minimal $40 \%$ untuk perahu motor pembagian hasil untuk $A B K$. Namun penelitian Yonvitner (2014) mengungkapkan bahwa depresiasi alat (perahu dan alat tangkap) menjadi biaya kotor atau tanggungan $A B K$ dan tidak diperhitungkan dalam sistem bagi hasil, sehingga nelayan pandega sebagai pemilik kapal memperoleh bagian lebih besar dibandingkan

Tabel 3. Biaya Variabel Rata-Rata Aktivitas Penangkapan Ikan di Kali Maro per Trip.

\begin{tabular}{lcccr}
\multicolumn{1}{c}{ Biaya per trip } & Kebutuhan & Satuan & Harga Satuan (Rp) & Total (Rp) \\
\hline Bensin & 17,5 & liter & 8.100 & 141.750 \\
Oli & 1,1 & liter & 42.000 & 45.710 \\
Bahan makanan & & & & 146.667 \\
Es & 62,5 & bungkus & 1.750 & 109.375 \\
Garam & 1,5 & bungkus & 9.000 & 13.500 \\
Biaya tambat & 0,03 & bulan & 175.000 & 5.833 \\
\hline Total rata-rata & \multicolumn{4}{c}{}
\end{tabular}


nelayan ABK (Yonvitner, 2014). Hasil penelitian di atas terjadi juga pada penelitian ini, kerusakan perahu dan alat tangkap menjadi beban ABK karena dimasukkan modal dan dikurangi saat pembagian hasil.

Aspek pemasaran dari hasil FGD menyatakan bahwa hasil tangkapan ikan langsung diambil oleh pemborong ikan sebagai agen dengan model pembayaran konsinyasi, yang berarti pembayaran kepada nelayan dilakukan setelah barang habis terjual. Dalam hal ini, pemborong ikan sudah memiliki pelanggan nelayan yang tetap sehingga pada saat pendaratan kapal, nelayan langsung menghubungi pemborong dan ikan pun dijemput oleh pemborong ke pelabuhan pendaratan. Hal ini tentu menghemat biaya distribusi pemasaran, namun pembayaran hasil tangkapan ikan biasanya dilakukan setelah ikan habis terjual atau paling lambat satu minggu setelah pengambilan ikan. Pemborong biasanya memiliki cold strorage sehingga ikan dapat disimpan.

Proses sortasi ikan dilakukan untuk memisahkan jenis ikan berdasarkan jenis dan besar kecilnya ikan. Semua jenis ikan dipisahkan berdasarkan ukurannya. Ikan-ikan besar yang berukuran $80-100 \mathrm{~cm}$ dijual per ekor seharga Rp70.000,00 sedangkan ikan kecil-kecil ukuran 15 - $25 \mathrm{~cm}$ dijual per kg seharga Rp30.000,00. Ada pula satuan yang biasa digunakan oleh nelayan, yaitu tali atau tusuk, disebut demikian karena ikan-ikan tersebut diikat menggunakan tali atau ditusuk bagian mulut hingga kepala ikan dengan menggunakan tali. Ikan-ikan ukuran lebih kecil dari $80 \mathrm{~cm}$ dibuat per tali. Dibedakan menjadi ikan sedang yang rata-rata berisi 2 ekor per tali yang dijual seharga Rp40.000,00 - Rp45.000,00 atau ikan ukuran lebih kecil berjumlah rata-rata 5 ekor per tali ( 1 tali/tusuk $=1 \mathrm{~kg}$ ) dengan harga yang sama (untuk jenis ikan kuru). Ikan-ikan dengan harga pasar yang rendah seperti ikan duri atau ikan kaca, dalam satu tali bisa terdiri dari 6 ekor ikan sedang atau 12 ekor ikan kecil dengan harga Rp20.000,00 - Rp35.000,00. Ikan Bandeng merupakan ikan yang tergolong mahal. Ikan bandeng berukuran $80 \mathrm{~cm}$ dijual per ekor dengan harga Rp50.000,00. Ikan bandeng kecil dan sedang dijual per tali berisi 2-3 ekor yang dijual dengan harga Rp50.000,00. Ikan kakap juga termasuk ikan dengan harga mahal. Ikan kakap besar bisa dijual dengan harga Rp70.000,00 - Rp150.000,00 per ekor. Harga tersebut merupakan harga di pemborong. Tidak ada TPI di sekitar muara sungai dan pesisir pantai, sehingga hampir semua hasil ikan langsung dibeli oleh pemborong atau pengusaha ikan asin (skala rumah tangga). Ada pula nelayan yang langsung menjual sendiri hasil tangkapannya ke pasar.

Dalam setiap transaksi, penjual (principal) biasanya mendelegasikan sebagian otoritasnya kepada agent yang membantu, misalnya dalam hal penjualan. Alasan utama para principal ini menggunakan agentkarena agentmerupakan orang yang ahli dan memiliki informasi yang tidak dimiliki oleh principal. Bagaimana principal memastikan agent melakukan hal yang terbaik untuk principal? Kondisi yang tidak adil dapat menimbulkan masalah pada hubungan ini. Prinsip teori agent-principal adalah tradeoff (Miller, 2008). Hubungan antara pemborong dan nelayan di Kali Maro, merupakan salah satu fenomena agent principle. Namun, nampaknya belum terjadi hubungan principal agent yang tidak menguntungkan antara pemborong dan pemilik kapal, seperti yang biasa terjadi di daerah pesisir lainnya. Walaupun ada pula pemilik perahu semang atau pemborong yang memberikan modal untuk usaha penangkapan tersebut, misalnya dengan pemberian es batu atau garam untuk hasil tangkapan ikan. Hal ini dilakukan sebagai bentuk loyalitas pemborong langganan dan mengikat nelayan. Belum adanya keluhan nelayan karena hubungan ini, diduga karena biaya operasional kapal yang tidak terlalu besar untuk skala nelayan penangkap ikan di kali menyebabkan hubungan agent principle belum menjadi masalah. Salah satu cara yang dilakukan nelayan Kali Maro untuk meminimalisir modal penangkapan adalah mengurangi tenaga kerja. Ada nelayan yang tidak menggunakan tenaga kerja baik dalam keluarga maupun luar keluarga, sehingga tidak ada sistem bagi hasil dengan anak buah kapal dan juga akan mengurangi bahan makanan yang harus disediakan. Penelitian Fargomeli (2014) di Halmahera Timur terhadap kelompok nelayan pesisir, kelompok masyarakat ini sulit untuk meningkatkan taraf hidupnya karena sulitnya akses menuju permodalan dari pemerintah sehingga terjebak dengan adanya fenomena patron-client antara nelayan dan tengkulak, sehingga mereka tetap hidup di bawah garis kemiskinan. Sementara nelayan di perairan umum daratan Kabupaten Ogan Komering Ilir, Sumatra Selatan, merasakan adanya hubungan yang saling menguntungkan antara patron (pedagang pengumpul) dan klien (nelayan), terutama dalam hal peminjaman modal kerja berupa biaya umpan dan sewa lelang serta penjualan ikan dengan harga yang sesuai harga pasar (Firdaus \& Shafitri, 2013). 
Solusi belum ada untuk mengatasi masalah principal agent yang tidak adil, masing-masing permasalahan sangat tergantung pada konteks pengelolaan manajemen dan usahanya (Miller, 2008).

Proses sortasi terhadap jenis dan berat ikan dilakukan di pelabuhan pendaratan dan dilakukan sendiri pemilik kapal atau anak buah kapal. Nelayan maupun pemborong tidak menggunakan satuan internasional untuk menghitung berat ikan, hanya berdasarkan perkiraan berat dan pandangan fisik ikan. Harga ditentukan oleh pemborong, rata-rata hasil penjualan per trip berkisar Rp500.000,00 Rp1.000.000,00 untuk penjualan hasil ikan maupun gelembung dari ikan kakap. Hasil ini masih dikurangi dengan upah tenaga kerja, pembagian dengan pemilik semang dan dipotong dengan bahan makanan. Rata-rata bersih yang diperoleh oleh ABK berkisar Rp50.000,00 - Rp175.000,00 per trip atau sekitar Rp1.000.000,00 - Rp3.500.000,00 per bulan. Penelitian Vibriyanti (2019) yang meneliti sosial ekonomi nelayan tangkap di Kota Kendari menyebutkan bahwa pada saat musim paceklik pendapatan nelayan rata-rata Rp1.600.000,00 sedangkan pada musim ikan rata-rata sebesar Rp3.500.000,00. Hasil penelitian ini kurang lebih sama dengan strukturpendapatan nelayan KaliMaro di Merauke. Bandingkan dengan tingkat pendapatan nelayan di Teluk Magdalena Mexico, pendapatan nelayan berada pada kisaran 4.142,3 - 8.062,5 PesoMexican (Rp3.021.352,19 - Rp5.880.706,87) (Marin-Monroy \& Ojeda-Rui de la Pena, 2016). Distribusi pendapatan di antara nelayan dapat diketahui melalui indeks gini rasio. Berdasarkan penelitian distribusi pendapatan nelayan di Kabupaten Seruyan, Kalimantan Selatan, nilai indeks gini rasio rata-rata sebesar 0,19545. Angka ini tergolong rendah, hal ini menunjukkan bahwa tidak ada perbedaan pendapatan yang signifikan di antara masyarakat nelayan di kabupaten tersebut (Winarti \& Permadi, 2015). Adapun faktor-faktor yang membedakan struktur pendapatan nelayan menurut Vibriyanti (2019) antara lain faktor internal berupa alat tangkap, kepemilikan armada, dan biaya produksi, sedangkan faktor eksternal berasal dari musim, harga ikan, pemasaran, dan degradasi sumber daya alam.

\section{MODAL SOSIAL SEBAGAI MEDIA PRODUKSI, BELAJAR, DAN PEMASARAN}

Aspek sosial ditinjau dari interaksi masyarakat dengan modal sosial yang dimilikinya serta keterlibatan dalam kelembagaan nelayan. Hampir sebagian besar peserta FGD telah tergabung dalam kelompok nelayan. Namun keterlibatannya dalam kelompok hanya ditujukan untuk prasyarat permohonan bantuan atau pemberian bantuan dari pemerintah. Pembentukan kelompok ini ada yang berhasil memperoleh bantuan namun ada pula yang tidak memperoleh bantuan. Bantuan yang biasanya diberikan berupa jaring, motor tempel, dan perahu motor. Penerima bantuan lebih banyak nelayan lokal dibandingkan pendatang. Beberapa pelatihan pernah juga diadakan untuk kelompok nelayan ini. Hanya $20 \%$ peserta yang mengaku pernah mendapatkan pelatihan, yaitu pelatihan perbaikan mesin motor tempel dan pelatihan produk pengolahan perikanan.

Kelompok yang dibentuk secara eksternal untuk tujuan permohonan bantuan biasanya tidak bertahan lama. Dari hasil wawancara diperoleh informasi bahwa saat penelitian ini berlangsung tidak ada kelompok nelayan yang aktif. Nelayan di Kali Maro baik lokal maupun pendatang tidak terbiasa melakukan aktivitas secara berkelompok. Misalnya, pertemuan rutin untuk meningkatkan kapasitas atau sekedar sharing berbagi informasi. Pembentukan kelompok dipaksakan berdasarkan kebutuhan untuk permohonan atau penyaluran bantuan. Saat ini, kelompok-kelompok tersebut sudah tidak aktif. Pembentukan koperasi pun dulu telah digagas oleh pemerintah namun tidak berjalan dengan baik, dan akhirnya koperasi tersebut tidak beroperasi kembali. Ada pula kelompok yang dibentuk oleh Coastal Community Development Project - International Fund for Agricultural Development (CCDP-IFAD) dengan kelompok pengolahan dan penangkapan ikan. Kelompok pengolahan terdiri dari istri-istri nelayan yang turut membantu meningkatkan pendapatan keluarga dan kelompok penangkapan adalah kelompok bapak-bapak nelayan yang mendukung pemenuhan bahan baku untuk produk pengolahan perikanan. Kelompok ini masih ada namun peserta FGD tidak ada yang bergabung dalam kelompok tersebut.

Keterlibatan nelayan dalam kelompok memungkinkan terbangunnya modal sosial bagi nelayan terutama dalam hal proses produksi, media belajar, dan pemasaran. Fungsi kelompok sebagai mediator bagi kelancaran bisnis penangkapan ikan belum dipahami dengan baik oleh masyarakat. Dari hasil FGD dapat dianalisis bahwa, nelayan belum memahami dan merasakan manfaat lain dalam berkelompok selain untuk meminta bantuan. Dalam hal ini, nelayan nampaknya merasakan manfaat 
berkelompok sebagai media produksi, tetapi belum merasakan manfaat lain seperti media belajar antar nelayan maupun untuk jejaring pemasaran hasil perikanan. Jaringan sosial nelayan dengan pelaku usaha lain hanya ditemukan pada kelompok yang dibentuk CCDP IFAD karena ada keterkaitan antara kelompok pengolahan dan kelompok penangkapan ikan. Kelompok ini telah mengupayakan bisnis hulu-hilir untuk meningkatkan pendapatan nelayan. Dalam konteks ini, sedikit banyak nelayan mulai merasakan kelompok sebagai media pemasaran dan membuka jejaring, namun sayangnya peserta FGD tidak ada yang terlibat dalam kelompok tersebut. Jaringan sosial antara nelayan dan pelaku pasar terjadi hanya dengan pemborong. Penjualan komoditi gelembung terdapat beberapa pelaku usaha sebagai pemborong. Nelayan telah memiliki langganan tetap untuk komoditi tersebut Sudaryana (2015) menyebutkan bahwa ada korelasi yang cukup besar antara kelembagaan $(60 \%)$ dan potensi ekonomi $(45 \%)$ terhadap kesejahteraan nelayan. Nampaknya, nelayan penangkap ikan di Kali Maro belum merasakan keuntungan mengembangkan sebuah kelembagaan dan membangun. Modal sosial yang dapat menjadi salah satu faktor meningkatkan kesejahteraan nelayan. Hingga saat ini, nelayan menggunakan kelompok hanya sebagai prasyarat untuk meminta bantuan pendanaan maupun modal dan bukan berasal dari kebutuhan masyarakat. Oleh karena itu, meningkatkan akses terhadap kelembagaan, menumbuhkan modal sosial, pengaktifan koperasi menjadi sangat penting untuk mendukung kesejahteraan nelayan di Kali Maro.

Budaya sasi yang diberlakukan di beberapa kampung lokal untuk wilayah penangkapan ikan di kali tidak pernah diberlakukan di muara sungai karena wilayah administratif muara sungai lebih ke kota dan sudah banyak area beralih kepemilikan lahan kepada pendatang. Biasanya adat sasi berlaku untuk masyarakat lokal dengan pemilik dusun/lahan yang melakukan sasi. Pada wilayah kepala kali/hulu sungai masih ada yang menerapkan sasi, namun praktek sasi ini sudah jarang ditemukan. Tidak ada aturan informal baik dari adat maupun dari pihak gereja yang berlaku dalam aktivitas penangkapan ikan di Kali Maro. Pada wilayah hulu sungai, pemilik dusun atau ketua adat yang memiliki kewenangan. Oleh karena itu, nelayan yang menangkap ikan hingga ke hulu sungai biasanya meminta izin terlebih dahulu kepada ketua adat dan memberikan sejumlah uang secara sukarela, rata-rata $\mathrm{Rp} 100.000,00$ -
Rp400.000,00. Namun, tidak banyak nelayan yang melakukan pencarian ikan hingga ke hulu sungai, hanya pemilik kapal di atas kapasitas 2-5 ton yang dilengkapi dengan cold storage yang dapat mencapai hulu sungai Maro. Ketiadaan aturan penangkapan ikan di muara sungai, menyebabkan terjadinya kecenderungan over fishing dan kemungkinan praktek-praktek penangkapan ikan yang membahayakan lingkungan. Peranan kelembagaan sangat penting bagi pengelolaan dan pelestarian kawasan sungai, terutama kelembagaan yang bersifat informal. Hal ini dapat dibuktikan melalui penelitian peran kelembagaan lokal di Sulawesi Barat yang menunjukkan bahwa kelembagaan informal yang telah terinternalisasi dengan baik akan dapat membantu pengelolaan dan pelestarian kawasan sungai, dibandingkan dengan lembaga formal (Yusuf, Arief, Amiluddin, Ali, \& Indar, 2018). Namun, kondisi lemahnya modal sosial yang dipresentasikan dalam kelembagaan rupanya tidak hanya terjadi pada nelayan di Kali Maro. Hampir di sebagian besar pesisir Indonesia, terutama nelayan kecil di Kabupaten Indramayu juga mengalami hal yang sama, indeks modal sosial termasuk kategori buruk dibandingkan indeks pembangunan sumber daya manusia dan penghidupan nelayan (Triyanti \& Firdaus, 2016). Oleh karena itu, penguatan kelembagaan informal perlu dibangun dan dikembangkan di dalam kehidupan nelayan Kali Maro agar memudahkan dalam proses mobilisasi, penyebaran informasi, peningkatan kapasitas maupun menjadi representatif dalam diskusidiskusi kebijakan dan pelibatan nelayan dalam program pengembangan wilayah pesisir dan daerah aliran sungai (DAS) Kali Maro.

Perbaikan rantai pasok hasil produk perikanan dan membangun industri di bidang pengolahan hasil perikanan menjadi syarat mutlak untuk perbaikan kesejahteraan nelayan. Penelitian model manajemen rantai pasok industri perikanan yang berkelanjutan di Maluku, menunjukkan bahwa komunikasi dalam melakukan koordinasi rantai pasok diperlukan di antara para pelaku untuk mengoptimalkan sistem distribusi. Proses perdagangan juga akan lebih efesien dan menguntungkan jika perdagangan dilakukan secara berkelompok dengan kolaborasi yang baik antara pedagang dan pembeli. Setiap pelaku usaha harus mampu mengakses informasi pasar dan diperlukan pula pelatihan bagi nelayan untuk penanganan hasil tangkapan serta cara pengelompokan mutu dengan 
melibatkan kelompok dan tokoh masyarakat, dengan penyuluh perikanan dan pemerintah setempat lebih terlibat dalam pengembangan kapasitas nelayan dan membangun sistem jaringan logistik perikanan (Batubara, Maarif, Marimin, \& Irianto, 2017).

Konflik antar nelayan pada aktivitas penangkapan ikan di Kali Maro belum nampak. Hasil FGD, menunjukkan tidak ada kasus perebutan wilayah penangkapan ikan, nelayan memiliki wilayah penangkapan ikan favorit masingmasing dan jika saat menangkap ikan terlihat ada kapal penangkap ikan yang lain, maka mereka naik ke hulu atau mengatur waktu penangkapan ikan agar tidak bersamaan. Aktivitas penangkapan ikan di sungai dapat dilakukan kapan saja, namun biasanya nelayan tetap mempertimbangkan pola pasang surut laut. Armada dengan kapasitas yang lebih besar langsung menuju kepala kali sehingga memungkinkan nelayan-nelayan dengan kapasitas lebih kecil mengambil ikan di muara sungai atau sepanjang badan sungai. Selain nelayan, mereka tidak memiliki kompetitor lain dalam pemanfaatan DAS. Seiring perkembangan wilayah, kita perlu juga mempertimbangkan konflik yang mungkin terjadi dari adanya kepentingan berbagai pihak terhadap pemanfaatan sungai. Penelitian Assad (2006) yang mengamati karakteristik dan potensi konflik dalam aktivitas perikanan tangkap di Sungai Musi Sumatra Selatan, mengingatkan tentang adanya potensi konflik baik sektor internal penangkapan ikan maupun sektor lain yang menggunakan DAS sebagai bagian dari proses produksinya. Pemerintah setempat membagi wilayah penangkapan ikan melalui sistem lelang, yang ternyata menimbulkan konflik kepentingan sehingga merugikan nelayan kecil. Hal ini yang perlu dipertimbangkan sdalam pengelolaan wilayah DAS jika di kemudian hari terdapat beberapa sektor lain yang memanfaatkan DAS Kali Maro.

\section{PENUTUP}

Karakteristik nelayan di Kali Maro merupakan nelayan kecil dengan kepemilikan perahu kecil (semang) rata-rata 1 unit dengan kapasitas maksimum 2 ton. Jenis ikan yang diperoleh antara lain ikan kakap, ikan kuru, ikan kaca, ikan bandeng, ikan gulama, ikan duri, dan ikan herkules. Kalender musim menurut nelayan terbagi menjadi dua, yaitu musim ikan melimpah (Oktober - Februari) dan musim ombak yang menandakan sedikitnya tangkapan ikan (Maret
- September). Sistem penangkapan dilakukan sendiri dengan tenaga kerja didominasi dari dalam keluarga. Pemasaran melalui pemborong langganan dengan model konsinyasi. Kelembagaan nelayan belum berfungsi sepenuhnya sebagai produksi, media belajar dan pemasaran. Nelayan hanya memahami pembentukan kelompok sebagai bagian dari proses produksi terutama untuk prasyarat penerima bantuan. Regulasi secara adat hanya terjadi di hulu sungai, sedangkan di muara sungai tidak ada aturan informal maupun formal yang mengatur aktivitas perikanan di sungai. Biaya operasional per trip sebesar Rp462.835,00 dengan komponen terbesar bensin dan oli sebesar $42 \%$. Oleh karena itu ditemukan adanya hubungan principle agent yang tidak menguntungkan nelayan.

Ke depan, modal sosial nelayan untuk membentuk kelembagaan informal dan membangun regulasi yang mengatur aktivitas penangkapan ikan, pemasaran, sistem bagi hasil dengan ABK perlu diperkuat. Pemerintah daerah perlu menyediakan data spasial, peningkatan alat tangkap, modernisasi moda transportasi dan sistem penyimpanan hasil, sistem rantai pasok pemasaran dan membangun industri pengolahan hasil perikanan. Penelitian ini perlu dilanjutkan dengan penelitian yang bersifat kuantitatif terkait dengan skenario peningkatan ekonomi nelayan.

\section{UCAPAN TERIMA KASIH}

Ucapan terima kasih kepada Kementerian Riset, Teknologi dan Perguruan Tinggi yang telah memberi Hibah PKPT 2019. Kepada para informan yang telah memberikan sejumlah data yang dibutuhkan, nelayan Kali Maro, dan pihak Kelurahan Kamahedoga, Distrik Merauke, Papua.

\section{PERNYATAAN KONTRIBUSI PENULIS}

Maria Maghdalena Diana Widiastuti merupakan kontributor utama sebagai ahli di bidang sosial dan ekonomi secara umum, merancang model pertanyaan terstruktur, menentukan karakteristik peserta FGD dan analisis data FGD. Modesta Ranny Maturbongs dan Sisca Elviana merupakan kontributor anggota yang berkontribusi dalam hal pengumpulan data di lapangan, Chair Rani dan Andi Iqbal Burhanuddin merupakan kontributor anggota sebagai ahli perikanan dan advisor yang menelaah kontent naskah. 


\section{DAFTAR PUSTAKA}

Assad, A. I. (2006). Karakteristik dan Potensi Konflik dalam Aktivitas Perikanan Tangkap di Daerah Aliran Sungai Musi, Sumatera Selatan. BAWAL, 1(2), 20-23. doi:http://dx.doi.org/10.15578/ bawal.1.2.2006.61-64

Batubara, S. C., Maarif, M. S., Marimin, \& Irianto, H. E. (2017). Model Manajemen Rantai Pasok Industri Perikanan Tangkap Berkelanjutan di Propinsi Maluku. Marine Fisheries, 8(2), 137-148. doi:https://doi.org/10.29244/jmf.8.2.137-148

Dinas Perikanan dan Kelautan Kabupaten Merauke. (2018). Data produksi dan pemilik armada perahu. Merauke: Kabupaten Merauke.

Elviana, S., Modesta, M. R., Sunarni, S., Rani, C., \& Burhanuddin, A. I. (2019). Keragaman Jenis Ikan di Sungai Maro Pada Musim Peralihan I. DEPIK: Jurnal IImu-ilmu Perairan, Pesisir, dan Perikanan, 8(2), 97-107. doi:10.13170/depik.8.2.12128

Fargomeli, F. (2014). Interaksi Kelompok Nelayan dalam Meningkatkan Taraf Hidup di desa Tewil Kecamatan Sangaji, Kabupaten Maba Halmahera Timur. Acta Diurna, 3(3), 1-17. Retrieved from https://ejournal.unsrat.ac.id/index.php/actadiurnakomunikasi/article/view/5728

Firdaus, M., \& Huda, H. M. (2015). Pengelolaan Sumberdaya Ikan di Sungai (Studi Kasus: di Kabupaten Pesisir Selatan Provinsi Sumatera Barat). Buletin MARINA, 1(1), 41-47. doi:http:// dx.doi.org/10.15578/marina.v1i1.1026

Firdaus, M., \& Shafitri, N. (2013). Pola Hubungan Kerja Nelayan Perairan Umum Daratan di Kabupaten Ogan Komering Ilir, Provinsi Sumatera Selatan (Studi Kasus di Desa Berkat, Kecamatan Sirah Pulau Padang). Jurnal Kebijakan Sosial EKonomi Kelautan dan Perikanan, 3(2), 143-151. doi:http:// dx.doi.org/10.15578/jksekp.v3i2.319

Kelurahan Kamahedoga. (2020). Data Monografi Kelurahan. Distrik Merauke: Kelurahan Kamahedoga.

Kementerian Kelautan dan Perikanan. (2018). Kelautan dan Perikanan Dalam Angka. Jakarta: KKP.

Marin-Monroy, E. A., \& Ojeda-Rui de la Pena, M. A. (2016). The Role of Socioeconomic Disaggregrated Indicators for Fisheries Manajemen Decisions: The Case of Magdalena--Almejas Bay, BCS Mexico. Fisheries Research, 177, 116-123. doi:http://dx.doi.org/10.1016/j. fishres.2016.01.009

Miller, G. J. (2008). Solutions to principal-agent in Firms. Dalam C. Menard, \& M. M. Shierly, Handbook of New Institutional Economics (hal. 349-370). Germany: Springer.
Mote, N., Ayarau, S., \& Sisca, E. (2019). Kelimpahan Jenis Ikan di Muara Sungai Maro Kelurahan Karang Indah Merauke Papua. Aquatik Science: Jurnal IImu Perairan, 1(1), 1-6. Retrieved from http://journal.ubb.ac.id/index.php/aquaticscience/ article/view/870

Nikijuluw, V. (2012). Aspek Sosial Ekonomi Masyarakat Pesisir dan Strategi Pemberdayaan mereka dalam Konteks Pengelolaan Sumberdaya Pesisir Secara Terpadu. Bogor: Kementerian Kelautan dan Perikanan.

Nontji, A. (1987). Laut Nusantara. Jakarta: Djambatan.

Patriana, R., \& Satria, A. (2013). Pola Adaptasi Nelayan terhadap Perubahan Iklim: Studi Kasus Nelayan Dusun Ciawitali, Desa Pamotan, Kecamatan Kali Pucang, Kabupaten Ciamis, Jawa Barat. Jurnal Sosial Ekonomi Kelautan dan Perikanan, 8(1), 11-23. doi: http://dx.doi.org/10.15578/jsekp. v8i1.1191

Sudaryana, B. (2015). Model Penanganan Kemiskinan Masyarakat Pantai Santolo Kabupaten Garut. Jurnal ATRABIS, 1(1), 11-21. Retrieved from https://jurnal.plb.ac.id/index.php/atrabis/article/ view/113

Sugianti, Y., \& Satria, H. (2007). Penangkapan Ikan di Sungai Maro, Merauke. BAWAL, 1(5), 197-201. doi:http://dx.doi.org/10.15578/ bawal.1.5.2007.197-201

Sumaila, U. R., Lam, V., Le Manach, F., Swartz, W., \& Pauly, D. (2016). Global Fisheries Subsidies: An updated estimate. Marine Policy, 69, 189-193. doi:http://dx.doi.org/10.1016/j. marpol.2015.12.026

Teraka, N. P. (2019). Penerpaan Budaya Adat Sasi pada Masyarakat Adat Suku Kimaam Kabupaten Merauke. Retrieved from academia: https://www. academia.edu/35219598/Penerapan_Budaya_ Adat_Sasi_Pada_Masyarakat_Adat_Suku_ Kimaam_Kab.Merauke

Triyanti, R., \& Firdaus, M. (2016). Tingkat Kesejahteraan Nelayan Skala Kecil dengan Pendekatan Penghidupan Berkelanjutan di Kabupaten Indramayu. Sosial Ekonomi Kelautan dan Perikanan, 11(1), 29-43. doi:http://dx.doi. org/10.15578/jsekp.v11i1.3170

Vibriyanti, D. (2019). Analisis Deskriptif Faktor Sosial Ekonomi yang Mempengaruhi Pendapatan Rumah Tangga Nelayan Tangkap (Studi Kasus: Kota Kendari). Jurnal Kebijakan Sosek Kelautan dan Perikanan, 9(1), 69-78. doi:http://dx.doi. org/10.15578/jksekp.v9i1.7440

Wahyuni, N. (2014). Bina Nusantara University. Diambil kembali dari binus.ac.id: https://qmc.binus. ac.id/2014/08/28/focus-group-discussion/ 
Widiastuti, M., \& Sunarni. (2018). Comparative Study of Social Economic Local and Migrant Fisherman in Arafura Beach, Merauke Papua. 1st International Conference on Social Science ICSS 2018. 226. Bali, Indonesia: Atlantis Press. doi:https://doi. org/10.2991/icss-18.2018.298

Winarti, L., \& Permadi, R. (2015). Distribusi Pendapatan Rumah Tangga Nelayan (Studi kasus di desa Sungai Bakau Kecamatan Seruyan Hilir Timur dan Desa Sungai Undang Kecamatan Seruyan Hilir Kabupaten Seruyan. Ziraa'ah Majalah IImiah Pertanian, 40(3), 203-211. doi:http://dx.doi. org/10.31602/zmip.v40i3.234

Yonvitner. (2014). Rekonstruksi UU Sistem Bagi Hasil Perikanan Pro Nelayan Kecil. Risalah Kebijakan Pertanian dan Lingkungan, 1(3), 192-196. doi:https://doi.org/10.20957/jkebijakan. v1i3.10296

Yusuf, D., Arief, A. A., Amiluddin, Ali, S. A., \& Indar, M. Y. (2018). Analisis Peran Kelembagaan Lokal Nelayan dan Strategi Pengembangannya dalam Pengelolaan dan Pemanfaatan Telur Ikan Terbang di Kabupaten Polman Sulawesi Barat. Jurnal Akuatika, 3(1), 1-9. doi: https://doi.org/10.24198/ jaki.v3i1.23390 